\title{
Phytochemical screening of two Ilam native plants Ziziphus nummularia (Burm.f.) Wight \& Arn. and Ziziphus spina-christi (Mill.) Georgi using HS-SPME and GC-MS spectroscopy
}

\author{
Mahmoud Bahmani ${ }^{1}$, Anahita Jalilian ${ }^{2}$, Iraj Salimikia ${ }^{3}$, Somayeh Shahsavari ${ }^{1} \&$ Naser Abbasi $^{*}$ \\ ${ }^{1}$ Biotechnology and Medicinal Plants Research Center, Ilam University of Medical Sciences, Ilam, Iran \\ ${ }^{2}$ Department of Obstetrics and Gynecology, School of Medicine, Ilam University of Medical Sciences, Ilam, Iran \\ ${ }^{3}$ Department of Pharmacognosy, School of Pharmacy, Razi Herbal Medicines Research Center, Lorestan University of Medical Sciences, \\ Khorramabad, Iran \\ *Email: ilamfarma@gmail.com
}

\section{ARTICLE HISTORY}

Received: 24 December 2019

Accepted: 02 February 2020

Published: 07 May 2020

\section{KEYWORDS}

Ziziphus nummularia

Ziziphus spina-christi

chemical compounds

HS-SPME

GC-MS

\section{ABSTRACT}

Essential oils are aromatic compounds widely used in the perfumery, pharmaceutical and food industries. There are several methods to extract essential oils and extracts. These methods include distillation, pressure or scraping, pressing and razor technique, headspace solid-phase micro extraction (HS-SPME), solvent extraction, extraction by bioactive hydrolyzing enzymes, and $\mathrm{CO}_{2}$ extraction. The aim of this study was to investigate the amounts of active ingredients of essential oils of medicinal plants Ziziphus nummularia and Ziziphus spina-christi by HS-SPME so that it can more easily move towards production of effective herbal remedies by identifying the main and active ingredients of the plants. The main chemical compound of $Z$. spina-christi essential oil was found to be transcaryophyllene (17.31\%), followed by alpha-pinene (15.50\%), beta-caryophyllene (10.86\%), and betapinene $(7.32 \%)$. The main compound of Z. nummularia essential oil was tetradecane $(16.76 \%)$, followed by hexadecane (9.35\%), dl-limonene (5.75\%), cyclohexan-1-ol, 3 meth (5.54\%), transcaryophyllene (5.47\%), and beta-myrcene (5.28\%). Chemical compounds of Ziziphus spina-christi included carbobicyclic or bicycleheptane, sesquiterpenes derived from germacrene, bicyclic monoterpenes, and monoterpenes, while the main compounds of $Z$. nummularia included monoterpenes, aliphatic hydrocarbons, alkane hydrocarbons, primary terpene compounds, and decarbonated alcohol. Identification of chemical and biological constituents of essential oils of medicinal plants is a valuable way to identify medicinal compounds that can be used to treat diseases by combining the traditional effects and the main compounds in the experimental pharmacy studies.

\section{Introduction}

Medicinal herbs are used for the treatment of variety of diseases and disorders (1-7). Herbs exert their effect through the active ingredients and antioxidants available (4-10). Ziziphus is an important genus of medicinal herbs that is important in traditional medicine. It is a genus of thorny trees and shrubs belonging to the Rhamnaceae family. There are about 3 species of Ziziphus that are distributed in tropical and subtropical regions. The fruit of this tree, also called Ziziphus, is edible. These trees are abundant in the wild. The trees are found in the tropical, western, and southern coasts of Iran and mainly in Ilam, Khouzestan, Sistan and Balouchestan, Hormozgan, Kerman, Fars and Bushehr provinces. The plants are found scattered and people use its fruit (11). Ziziphus species include Ziziphus abyssinica, Z. lotus, Z. mauritiana, Z. mucronata, Z. nummularia, Z. spinachristi and $Z$. zizyphus (12). Zizyphus spina-christi belongs to Kingdom: Plantae, Order: Rosales. This plant is a tree of approximately 2 meters height with small, heart-shaped and extended leaves and three prominent veins, with its earrings turning into thorn. An important feature is the secretory system producing mucilage and gum, which contains single

(c) Bahmani et al. (2020). This is an open-access article distributed under the terms of the Creative Commons Attribution License, which permits unrestricted use, distribution and reproduction in any medium, provided the original author and source are credited (https://creativecommons.org/licenses/by/4.0/).

To cite this article: Bahmani M, Jalilian A, Salimikia I, Shahsavari S, Abbasi N. Phytochemical screening of two llam native plants Ziziphus nummularia (Burm.f.) Wight \& Arn. and Ziziphus spina-christi (Mill.) Georgi using HS-SPME and GC-MS spectroscopy. Plant Science Today 2020;7(2):275-280.

https://doi.org/10.14719/pst.2020.7.2.714 
cells or secretory bags found in the skin and core of the stem in the parenchyma tissue of the vascular bundle around the veins of the leaf and petioles as well as outer part of the fruit $(13,14)$. In traditional medicine, Z. spina-christi is used for wound healing and hair growth and as an antimicrobial, antifungal, laxative, anti-bronchitis, analgesic, immune systemboosting, skin-refreshing, and detoxifying agent, to treat bone fracture, cancer, low back pain, to lose weight, etc. (15-17). The plant contains important medicinal compounds such as alkaloids, flavonoids, glycosides, saponins and essential oils $(18,19)$. It is found in Iran, Pakistan, Afghanistan, Iraq, Egypt and Israel (20-22). Z. nummularia or Ramilak is another species of Ziziphus is found in Afghanistan, India, Iran, Lebanon, Pakistan, Zimbabwe, Mauritania, Nigeria and Uganda. Z. nummularia leaves have been widely used in traditional medicine for the treatment of cold, skin diseases, pain, diabetes, wounds and also as an anti-inflammatory, antibacterial, antifungal, sedative and hypnotic agent (23-29). Phytochemical analysis revealed the presence of a number of phyto constituents such as flavonoids, tannins, sterols, saponins, pectins, glycosides, alkaloids and tripepnoids. Cyclopeptide alkaloids have been identified as active ingredient of Ziziphus nummularia (25-29).

Ziziphus spina-christi and Z. nummularia are used as edible fruits, jams, health products for skin and hair and medicinal effect. In traditional and persian medicine of Iran and especially in Ilam province (west of Iran) from fruits and leaves of Ziziphus spina-christi and Z. mauritiana are widely used as medicinal and hygienic products so, In this study, we tried to understand the effective ingredients of these two plant. Finally, the active ingredients of these herbs will be helpful to produce effective pharmaceutical products.

\section{Materials and Methods}

\section{Plant preparation}

In October-November 2019, two species Z. spinachristi (Fig. 1) and Z. nummularia (Fig. 2) were procured from Dehloran County (south of Ilam province, west of Iran). The plants were identified and confirmed using morphological keys of Ilam Province Plant Flora at Ilam University of Medical Sciences Biotechnology and Medicinal Research Center. The collected plants were cleaned and dried in the shade in the open air. The dried plants were pulverized by a plant mixer and analyzed by HSSPME for chemical composition.

\section{Identification of chemical compounds by SPME-HS method}

The essential oil of the plant was extracted by HSSPME technique. About 2 gms of dried plant (from each plant separately) and its powder were placed in standard vial device and the vial temperature was set at $60-70{ }^{\circ} \mathrm{C}$. These optimum temperature conditions will saturate the vapor content of the substances in the plant essential oil in the headspace of the solid surface (Headspace of the (the vial is a part of the HSSPME equipment). The SPME syringe with a lid on it

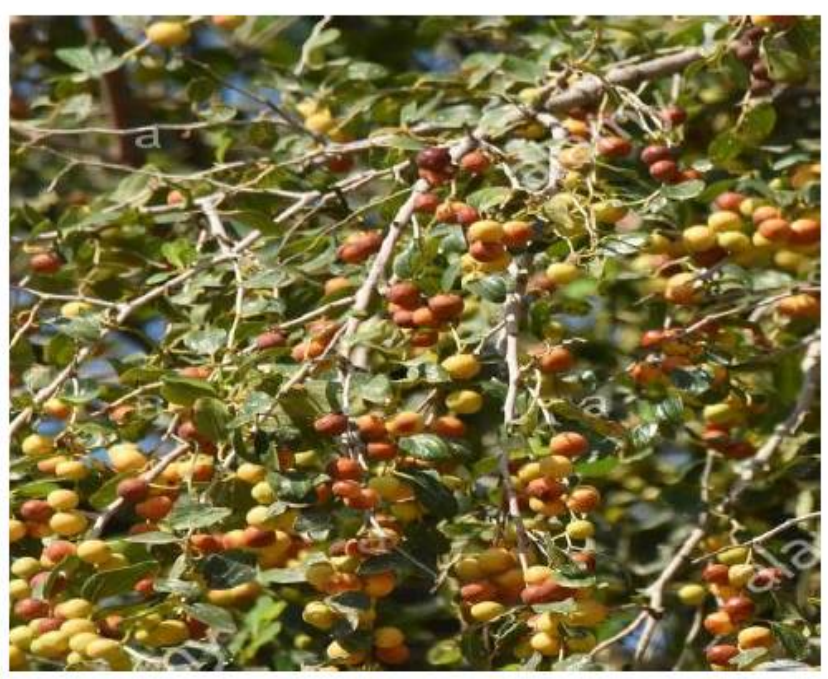

Fig. 1. Ziziphus spina-christi

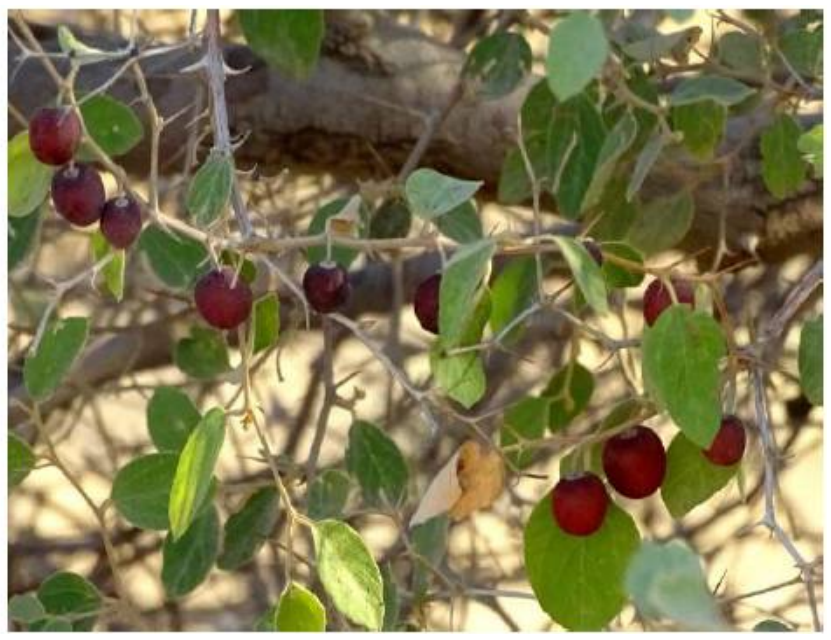

Fig. 2. Ziziphus nummularia

was then placed in the headspace of the vial and the essential oils in the vial was absorbed by the silica phase in the instrument needle. After the silica fiber was allowed to sufficiently saturate with volatile components, the fiber was directly placed into the GC/MS input section and the essential oils in the fiber in the vial were adsorbed due to the temperature of the input and then the essential oils in HS-SPME device entered into the GC/MS apparatus for identification (30).

\section{HS-SPME method}

About $2 \mathrm{gm}$ of each plant extract was used for analysis. The device condition was as follows: Gas chromatograph (Agilent 6890N) was coupled with Agilent 5973 Mass detector; Column: HP-5. (30 m length $\times 0.25 \mathrm{~mm}$ (ID) $\times 0.25 \mu \mathrm{m}$ (stationary phase thickness); Injector type: split/splitless and column temperature program: $50{ }^{\circ} \mathrm{C}$, hold time $0.00 \mathrm{~min}$ and rate of $-^{\circ} \mathrm{C} / \mathrm{min}$; temperature $200{ }^{\circ} \mathrm{C}$, hold time, 0.00 min and rate of $5{ }^{\circ} \mathrm{C} / \mathrm{min}$ and temperature $240{ }^{\circ} \mathrm{C}$, hold time $0.00 \mathrm{~min}$ and rate of $10^{\circ} \mathrm{C} / \mathrm{min}$. Carrier gas: He (99.999\%); Injection type: splitless; Library: Wiley $7 \mathrm{n}$; Injector temperature: $250{ }^{\circ} \mathrm{C}$ and flow rate: 0.9 $\mathrm{mL} / \mathrm{min}$. Extraction mode: (HSSPME); SMPE fiber: PDMS $100 \mu \mathrm{m}$ thickness (SUPELCO); sample weight: $0.5 \mathrm{gm}$; extraction temperature: $60{ }^{\circ} \mathrm{C}$; extraction time: $20 \mathrm{~min}$; sonication time: $10 \mathrm{~min}$ (Euronda 
sonication instrument, Italy) and desorption time in GC-MS injector port: 3 min (31).

\section{Results}

In this study, essential oils of two plant species $Z$. nummularia and $Z$. spina-christi were extracted by HSSPME and analyzed by GC-MS. Based on the results, a total of 41 chemical compounds were isolated from $Z$. spina-christi essential oil (Table 1). The results of phytochemical analysis showed that the main

Table 1. Identified compounds of Ziziphus spina-christi essential oils of by HS-SPME (GC-MS) method

\begin{tabular}{|c|c|c|c|}
\hline No. & Retention time & Compound & $\%$ \\
\hline 1 & 5.942 & a-Thujene & 1.53 \\
\hline 2 & 6.133 & a-Pinene & 15.50 \\
\hline 3 & 7.07 & Sabinene & 2.54 \\
\hline 4 & 7.170 & $\beta$-Pinene & 7.32 \\
\hline 5 & 7.508 & $\beta$-Myrcene & 6.26 \\
\hline 6 & 7.88 & 1-Phellandrene & 0.61 \\
\hline 7 & 8.018 & Delta 3-Carene & 0.68 \\
\hline 8 & 8.22 & 4-Carene & 0.14 \\
\hline 9 & 8.560 & $\beta$-Phellandrene & 10.86 \\
\hline 10 & 8.735 & cis-Ocimene & 2.02 \\
\hline 11 & 9.03 & trans-.beta.-Ocimene & 0.26 \\
\hline 12 & 9.348 & $\gamma$-Terpinene & 0.30 \\
\hline 13 & 9.698 & trans-Sabinene hydrate & 0.65 \\
\hline 14 & 10.242 & Terpinolen & 0.05 \\
\hline 15 & 10.583 & Linalool & 0.28 \\
\hline 16 & 11.748 & trans-Pinocarveol & 0.23 \\
\hline 17 & 12.082 & L-Menthone & 4.90 \\
\hline 18 & 12.332 & Menthofuran & 2.43 \\
\hline 19 & 12.737 & Menthol & 1.28 \\
\hline 20 & 12.99 & 3-p-Menthanol & 0.50 \\
\hline 21 & 13.053 & trans-Carane & 0.67 \\
\hline 22 & 13.23 & A-Terpineol & 1.07 \\
\hline 23 & 14.481 & Pulegone & 0.30 \\
\hline 24 & 14.937 & Piperitone & 0.21 \\
\hline 25 & 15.898 & Carane & 4.75 \\
\hline 26 & 16.295 & cis-Carane & 0.27 \\
\hline 27 & 17.848 & a-Muurolene & 0.16 \\
\hline 28 & 18.088 & a-Copaene & 2.46 \\
\hline 29 & 18.338 & a-Bourbonene & 0.23 \\
\hline 30 & 18.448 & $\beta$-Cubebene & 0.08 \\
\hline 31 & 18.517 & $\beta$-elemene & 0.32 \\
\hline 32 & 19.266 & trans-Caryophyllene & 17.31 \\
\hline 33 & 19.579 & a-Bergamotene & 0.64 \\
\hline 34 & 20.121 & trans- $\beta$-Farnesene & 1.70 \\
\hline 35 & 20.814 & Germacrene-D & 3.84 \\
\hline 36 & 20.957 & $\beta$-Selinene & 0.70 \\
\hline 37 & 21.185 & Bicyclogermacrene & 4.62 \\
\hline 38 & 21.805 & $\delta$-Cadinene & 1.15 \\
\hline 39 & 22.207 & CIS-a-Bisabolene & 0.13 \\
\hline 40 & 23.328 & Caryophyllene oxide & 0.93 \\
\hline 41 & 23.581 & p-Menth-3-en-9-ol & 0.10 \\
\hline
\end{tabular}

chemical compounds of $Z$. spina-christi essential oils was trans-caryophyllene (17.31\%), followed by alphapinene (15.50\%), beta-caryophyllene (10.86\%), and beta-pinene (7.32\%). The other compounds of the essential oil of $Z$. spina-christi are are listed in Table 1. Based on the results of GC-MS analysis, a total of 39 chemical compounds were also isolated from the species $Z$. nummularia. The main compound of $Z$. nummularia essential oil was tetradecane (16.76\%), followed by hexadecane (9.35\%), dl-limonene (5.75\%), cyclohexan-1-ol, 3 meth (5.54\%), trans-caryophyllene (5.47\%), and beta-myrcene (5.28\%). Supplementary information on other chemical compounds of the essential oil of $Z$. nummularia is given in Table 2 .

Ziziphus spina-christi essential oils was transcaryophyllene (17.31\%), followed by alpha-pinene (15.50\%), beta-caryophyllene (10.86\%), and beta-

Table 2. Identified compounds in the essential oil of Ziziphus nummularia by HS-SPME (GC-MS)

\begin{tabular}{|c|c|c|c|}
\hline No. & $\begin{array}{l}\text { Retention } \\
\text { time }\end{array}$ & Compound & $\%$ \\
\hline 1 & 6.669 & a- Pinene & 2.82 \\
\hline 2 & 7.846 & $\beta$-Pinene & 1.78 \\
\hline 3 & 8.298 & $\beta$-Myrcene & 5.28 \\
\hline 4 & 9.561 & dl-Limonene & 5.75 \\
\hline 5 & 12.018 & Nonanal & 1.40 \\
\hline 6 & 13.761 & Menthone & 2.20 \\
\hline 7 & 14.533 & Menthol & 1.23 \\
\hline 8 & 14.63 & Pyrazine, 2-methoxy-3-(2-methylpropyl) & 3.60 \\
\hline 9 & 15.19 & Dodecane & 4.87 \\
\hline 10 & 15.487 & Decanal & 1.24 \\
\hline 11 & 18.459 & Menthyl acetate & 1.88 \\
\hline 12 & 18.557 & Tridecane & 1.45 \\
\hline 13 & 20.311 & 5-Methyltridecane & 1.20 \\
\hline 14 & 20.843 & 2-Methyltetradecane & 1.27 \\
\hline 15 & 21.106 & Copaene & 1.93 \\
\hline 16 & 21.666 & Cyclotetradecane & 1.44 \\
\hline 17 & 21.774 & Tetradecane & 16.76 \\
\hline 18 & 22.46 & trans-Caryophyllene & 5.47 \\
\hline 19 & 22.877 & a-Zingiberene & 0.27 \\
\hline 20 & 22.98 & a-Guaiene & 1.26 \\
\hline 21 & 23.415 & trans-Geranylacetone & 1.33 \\
\hline 22 & 23.557 & Pentatriacontane & 0.94 \\
\hline 23 & 24.089 & a-Amorphene & 0.78 \\
\hline 24 & 24.398 & $\beta$-Ionone & 2.73 \\
\hline 25 & 24.615 & Pentadecane & 1.93 \\
\hline 26 & 24.746 & a-Muurolene & 0.99 \\
\hline 27 & 25.369 & $\delta$-Cadinene & 1.85 \\
\hline 28 & 25.832 & Methylundecane & 1.30 \\
\hline 29 & 25.986 & 5-Methylpentadecane & 1.13 \\
\hline 30 & 26.455 & 3-Methylpentadecane & 0.38 \\
\hline 31 & 27.192 & Hexadecane & 9.35 \\
\hline 32 & 28.358 & Phytane & 1.43 \\
\hline 33 & 28.558 & Lanol & 0.54 \\
\hline 34 & 29.564 & Heptadecane & 1.52 \\
\hline 35 & 29.656 & 3-Cyclohexen-1-ol, 3-methyl- & 5.54 \\
\hline 36 & 31.37 & Octadecane & 1.51 \\
\hline 37 & 31.485 & Tritetracontane & 1.17 \\
\hline 38 & 31.965 & Tetrahydrogeranylacetone & 0.87 \\
\hline 39 & 33.153 & Dibutyl phthalate & 1.60 \\
\hline
\end{tabular}

pinene $(7.32 \%)$. The other compounds of the essential oil of $Z$. spina-christi are listed in Table 1.

Fig. 3 and 4 comparatively illustrate the chromatograms of the compounds of $Z$. spina-christi and $Z$. nummularia essential oils. Apart from the difference in the percentages of compounds of the two plants', as shown in the chromatogram (No. 3) and Table 1, the plant has 41 chemical compounds in total. The main compounds of $Z$. spina-christi included carbobicyclic or bicycleheptane compounds, sesquiterpene derived from germacrene, monoterpenes as bicyclic monoterpenes. The chromatogram of $Z$. nummularia showed that the plant has a total of 39 chemical compounds of which, the main compounds are monoterpenes, aliphatic hydrocarbons, alkane 


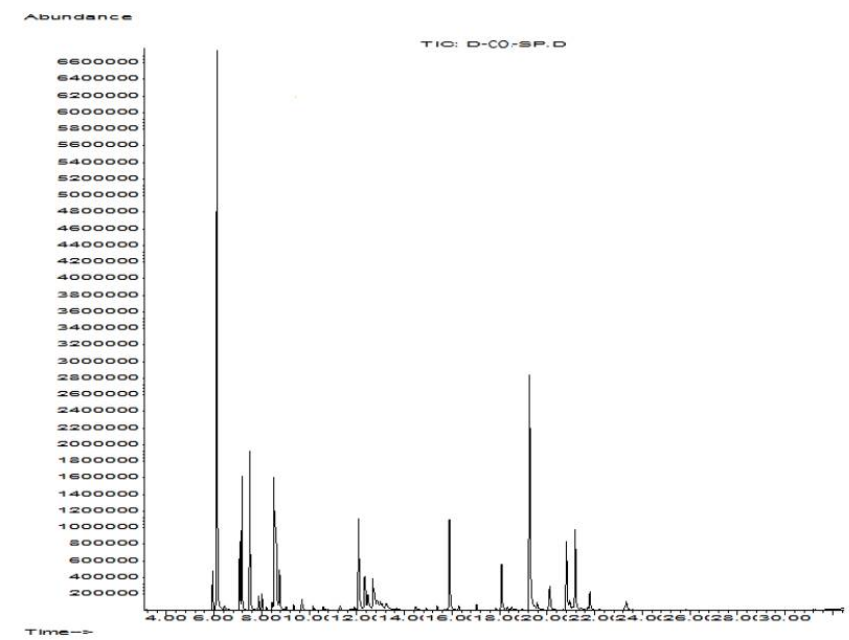

Fig. 3. Chromatogram of the essential oil of Ziziphus spina-christi.

hydrocarbons, primary terpenes and decarbonated alcohol.

Based on the results of GC-MS analysis, a total of 39 chemical compounds were also isolated from the species $Z$. nummularia. The main compound of $Z$. nummularia essential oil was tetradecane (16.76\%), followed by hexadecane (9.35\%), dl-limonene (5.75\%), cyclohexan-1-ol, 3 meth (5.54\%), transcaryophyllene $(5.47 \%)$ and beta-myrcene (5.28\%). A list of the main constituents along with the chemical formula and the chemical structure of the two plants are outlined in Table 3. View results of the phytochemical analysis show that there are common compounds between the two plants that differ in percentage. The results were reported in Table 4. Different compounds of $Z$. spina-christi are include $a$ Thujene, Menthofuran, Piperitone, Pulegone, Sabinene and $\gamma$-Terpinene. Also different compounds of $Z$. nummularia include Decanal, a-Zingiberene, aGuaiene, a-Amorphene, phytane and Lanol.

Table 3. Structure and chemical composition of the two plants

\begin{tabular}{|c|c|c|c|}
\hline \multicolumn{2}{|c|}{ Z. spina-christi } & \multicolumn{2}{|c|}{ Z. nummularia } \\
\hline Compound & $\begin{array}{l}\text { Chemical } \\
\text { formula }\end{array}$ & Compound & $\begin{array}{l}\text { Chemical } \\
\text { formula }\end{array}$ \\
\hline trans-caryophyllene & $\mathrm{C}_{15} \mathrm{H}_{24}$ & Tetradecane & $\mathrm{C}_{14} \mathrm{H}_{30}$ \\
\hline alpha-pinene & $\mathrm{C}_{10} \mathrm{H}_{16}$ & Hexadecane & $\mathrm{C}_{16} \mathrm{H}_{34}$ \\
\hline beta-caryophyllene & $\mathrm{C}_{15} \mathrm{H}_{24}$ & dl-limonene & $\mathrm{C}_{10} \mathrm{H}_{16}$ \\
\hline beta-pinene & $\mathrm{C}_{10} \mathrm{H}_{16}$ & $\begin{array}{l}\text { cyclohexan-1-ol, } 3 \\
\text { meth }\end{array}$ & $\mathrm{C}_{7} \mathrm{H}_{12 \mathrm{O}}$ \\
\hline
\end{tabular}

Table 4. Comparison of differences in the percentages of common constituents between the two medicinal plants

\begin{tabular}{lcc}
\hline \multirow{2}{*}{ Compound } & \multicolumn{2}{c}{ Medicinal plants } \\
\cline { 2 - 3 } & Z. spina-christi (\%) & Z. nummularia (\%) \\
\hline alpha-pinene & $15.50 \%$ & $2.82 \%$ \\
\hline Beta-pinene & $7.32 \%$ & $1.78 \%$ \\
\hline beta-myrcene & $6.26 \%$ & $5.28 \%$ \\
\hline trans-Caryophyllene & $17.31 \%$ & $5.47 \%$ \\
\hline a-Muurolene & $0.16 \%$ & $0.99 \%$ \\
\hline
\end{tabular}

\section{Discussion}

According to the studies (33-35), few phytochemical studies have been conducted on Ziziphus nummularia and Z. spina-christi (32). One of the important factors

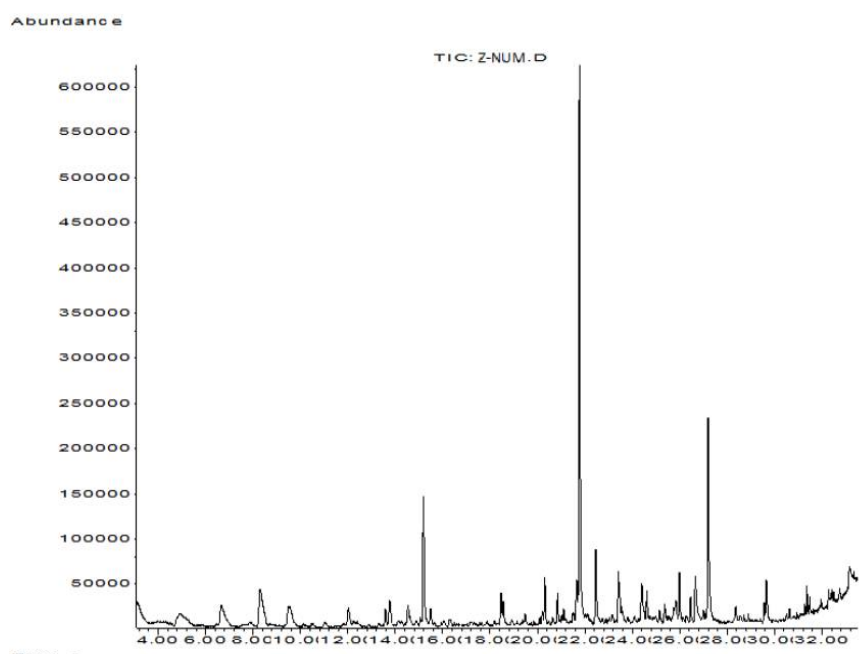

Fig. 4. Chromatogram of the essential oil of Ziziphus nummularia.

in the differences in the chemical composition of a particular species is the growth in different geographical areas and ecological conditions. Despite being part of the plant family Rhamnaceae, These factors have certain differences and similarities with respect to chemical composition and secondary metabolites. In a study, benzaldehyde, phenylacetaldehyde, phenylethylalcohol, benzeneacetonitrile, 2-ethyl hexanoic acid, octanoic acid, 2-methoxy 4- (1-Propanol) -6-acetate phenol, nonanoic acid, decanoic acid, 1-hydroxy 2,4,6trimethylbenzene and 5-hydroxymethyl-2-furaldehyde were identified from $Z$. spina-christi honey (33). Another study revealed that $Z$. spina-christi seed contained compounds such as 4-hydroxymethyl-1methyl pyrrolidine-2-carboxylic acid (less polar and major compound) and 4-hydroxy-4-hydroxymethyl-1methyl pyrrolidine -2-carboxylic acid (34). Chemical compounds of hexane and ethanolic extracts of $Z$. nummularia leaf revealed that hexane extract of the plant included 105 chemical compounds and its ethanolic extract included 56 chemical compounds including palmitic acid, linoleic acid, stearic acid, squalene, stigmasterol campesterol, vitamin E, geranyl linalool isomer, trans-geranylgeran oil, 1-eicosanol, gamma sitosterol, betulin, lupeol and phytol in the nhexane extract while in addition to palmitic acid, linoleic acid, gamma sitosterol, stigmasterol, phytol, squalene, oleic acid, tricosane, tetradecane, 2-methoxy4-vinylphenol, ethyl alpha-d-glucopyranoside and behenylbehenate were identified in the extracts of both extract (35). An investigation on the chemical constituents of $Z$. nummularia revealed that 4-hydroxycyclohexanone, 2,7-dimethyloctane-3,5-dione, heptacosane and 9,12-octadecadienoic acid methyl ester as the main compounds of the plant (36).

Hexadecanoic acid has antimicrobial, anti-allergic, antioxidant and pesticide effects (37-39). Octadecane has antifungal effect (40) and geranyl linalool isomer has antioxidant effects (41), partly explaining the properties of the two studied plants. The HS-SPME (GCMS) technique helps to identify the essential oil of the plants. Identifying the plant's active ingredients along with documentation of the traditional and ethnobotanical effects of those plants leads us to a better understanding of Ziziphus nummularia and Z. spina- 
christi pharmacological effects to produce natural and herbal remedies that are effective against diseases.

\section{Acknowledgements}

Authors would like to thank the Vice-chancellor for the Research and Technology Deputy of the Ilam University of Medical Sciences and Biotechnology and Medicinal Plants Research Center for funding this study. Grant's number is A-10-2667-1.

\section{Authors' contributions}

$\mathrm{MB}, \mathrm{NA}$ and $\mathrm{AJ}$ reviewed the literature and prepared the first draft of manuscript; NA, MB, AJ and IS reviewed the literature, helped in preparing first draft of manuscript, checked and corrected the grammar. This study was designed and performed by MB, SSH and NA. All authors read and approved the final report.

\section{Conflict of interests}

The authors declare that they have no conflict of interests.

\section{Funding/Support}

Biotechnology and Medicinal Plants Research Center, Ilam University of Medical Sciences has supported this research.

\section{References}

1. Abbaszadeh S, Karami N, Bahmani F, Abbasi N, Atefi E. Headache and herbal medicine: An ethnobotanical study of Shahrekord, Southwest of Iran. Plant Biotechnol Persa. 2019;1(1):4-9. http://pbp.medilam.ac.ir/article-1-35-en.html

2. Zangeneh MM, Ghaneialvar H, Akbaribazm M, Ghanimatdan M, Abbasi N, Goorani S, et al. Novel synthesis of Falcaria vulgaris lea extract conjugated copper nanoparticles with potent cytotoxicity, antioxidant, antifungal, antibacterial and cutaneous wound healing activities under in vitro and in vivo condition. Journal of Photochemistry and Photobiology B: Biology. 2019;197:111556. https://doi.org/10.1016/j.jphotobiol.2019.111556

3. Moayeri A, Azimi M, Karimi E, Aidy A, Abbasi N. Attenuation of morphine withdrawal syndrome by Prosopis farcta extract and its bioactive component luteolin in comparison with clonidine in rats. Med Sci Monitor Basic Res. 2018;24(9):151-58. https://doi.org/ 10.12659/MSMBR.909930

4. Bahmani M. A new method for promoting biologic synthesis and reducing the size of titanium dioxide nanoparticles (Tio2 NPs) synthesized by Origanum vulgare. Plant Biotechnol Persa. 2019;1(1):10-12. http://pbp.medilam.ac.ir/article-1-5-en.html

5. Bahmani M, Taherikalani M, Khaksarian M, Rafieian-Kopaei M, Ashrafi B, Nazer M, et al. The synergistic effect of hydroalcoholic extracts of Origanum vulgare, Hypericum perforatum and their active components carvacrol and hypericin against Staphylococcus aureus. Future Science OA. 2019;5(3):FSO371. https://doi.org/ 10.4155/fsoa-2018-0096

6. Abbasi N, Khosravi A, Aidy A, Shafiei M. Biphasic response to luteolin in MG-63 osteoblast-like cells under high glucose-induced oxidative stress. Iranian J Med Sci. 2016;41(2):118-25

7. Jabbari N, Gheibi P, Eftekhari Z. The therapeutic effects of isolated Eugenol of Syzygium aromaticum. Plant Biotechnol Persa. 2019;1(1):42-44. http://pbp.medilam.ac.ir/article-1-14-en.html
8. Karimi E, Abbasi S, Abbasi N. Thymol polymeric nanoparticle synthesis and its effects on the toxicity of high glucose on OEC cells: Involvement of growth factors and integrin-linked kinase. Drug Design, Development and Therapy. 2019;13:2513-32 https://doi.org/10.2147/DDDT.S214454

9. Bahmani F, Kazemeini H, Hoseinzadeh-Chahkandak F, Farkhondeh T, Sedaghat M. Sedation with medicinal plants: A review of medicinal plants with sedative properties in Iranian ethnobotanical documents. Plant Biotechnol Persa. 2019;1(1):13-24. http://pbp.medilam.ac.ir/article-1-11-en.html

10. Serna-Escolano V, Serrano M, Valero D, Rodríguez-López MI, Gabaldón JA, Castillo S, et al. Effect of Thymol and Carvacrol Encapsulated in Hp-B-Cyclodextrin by Two Inclusion Methods against Geotrichumcitri-aurantii. Food Microbiology \& Safety. 2019;84(6):1513-21. https://doi.org/10.1111/1750-3841.14670

11. Saied SA, Gebaur J, Hammer K, Buerkert A. Ziziphus spina-christi (L.) Willd: A multipurpose fruit tree. Genet Rosour Crop Evol. 2008; 55:929-37. https://doi.org/10.1007/s10722-007-9299-1

12. Kadioglu O, Jacob S, Bohnert S, Nass J, Saeed ME, Khalid H, et al. Evaluating ancient Egyptian prescriptions today: Anti-inflammatory activity of Ziziphus spina-christi. Phytomedicine. 2016;23(3):293-306. https://doi.org/10.1016/j.phymed.2016.01.004

13. Jiang JG, Huang XJ, Chen J and Lin QS. Comparison of sedative and hypnotic effects of flavonoids, saponins and polysaccharids extract from semen Ziziphus jujube. Natural Product Research. 2007;21:310-20. https://doi.org/10.1080/14786410701192827

14. Amal H, Eman IA. Effect of Ziziphus leaves extract on mice suffering from ehrlich ascites carcinoma. Nature Sci. 2010;8:234-44

15. Kaur R, Kapoor K, Kaur H. Plants as a source of anticancer agents. J Nat Prod Plant Resour. 2011;1:119-24

16. Abdel-Wahhab MA, Omara EA, Abdel-Gali MM, Hassan NS, Nada SA, Saeed A, et al. A Ziziphus spina-christi extract protects against aflatoxin B1-Intitiated hepatic carcinogenicity. Afr J Tradit Complement Altern Med. 2007;4:248-56

17. Shahat AA, Pieters L, Apers S, Nazeif NM, Abdel-Azim NS, Berghe DV, et al. Chemical and biological investigations on Ziziphus spinachristi L. Phytother Res. 2001;9:593-97. https://doi.org/10.1002/ ptr.883

18. Abalaka M, Mann A, Adeyemo S. Studies on in-vitro antioxidant and free radical scavenging potential and phytochemical screening of leaves of Ziziphus mauritiana L. and Ziziphus spina-christi L. compared with Ascorbic acid. J Med Genet Genomics. 2011;3(2):2834

19. El-Kamali HH, Mahjoub SAT. Antibacterial activity of Francoeuria crispa, Pulicaria undulata, Ziziphus spina-christi and Cucurbita pepo against seven standard pathogenic bacteria. Ethnobot Leaflets. 2009;(6):6. https://opensiuc.lib.siu.edu/ebl/vol2009/iss6/6

20. Abbasi AM, Khan MA, Khan N, Shah MH. Ethnobotanical survey of medicinally important wild edible fruits species used by tribal communities of Lesser Himalayas-Pakistan. J Ethnopharmacol. 2013; 48:528-36. https://doi.org/10.1016/j.jep.2013.04.050

21. Bachaya HA, Iqbal Z, Khan MN, Jabbar A. Anthelmintic activity of Ziziphus nummularia (bark) and Acacia nilotica (fruit) against Trichostrongylid nematodes of sheep. J Ethnopharmacol. 2009; 123:325-29. https://doi.org/10.1016/j.jep.2009.02.043

22. Desai AG, Qazi GN, Ganju RK, El-Tamer M, Singh J, Saxena AK, et al. Medicinal plants and cancer chemoprevention. Curr Drug Metab. 2008;9:581-91. https://doi.org/10.2174/138920008785821657

23. Ullah M, Khan MU, Mahmood A, Malik RN, Hussain M, Wazir SM, et al. An ethnobotanical survey of indigenous medicinal plants in Wana district south Waziristan agency, Pakistan. J Ethnopharmacol. 2013;150(3):918-24

24. Goyal M, Ghosh M, Nagori BP, Sasmal D. Analgesic and anti-inflammatory studies of cyclopeptide alkaloid fraction of leaves of Ziziyphus nummularia. Saudi Journal of Biological Sciences. 2013 20(4):365-71. https://doi.org/10.1016/j.jep.2013.09.032

25. Bodroth RP, Das M. Phytochemical screening and antimicrobial activity of ethanol and chloroform extract of Ziziphus nummularis Wt. \& Arm. African Journal of Biotechnology. 2012;11(21):4929-33

26. Yusufoglu HS. Topical anti-inflammatory and wound healing activities of herbal gel of Ziziphus nummularia L. (F. Rhamnaceae) 
leaf extract. International Journal of Pharmacology. 2011; 7(8):862-67. https://doi.org/10.3923/ijp.2011.862.867

27. Ray SD, Ray S, Zia-Ul-Haq M, De Feo V, Dewanjee S. Pharmacological basis of the use of the root bark of Ziziphus nummularia Aubrev. (Rhamnaceae) as anti-inflammatory agent. BMC Complementary and Alternative Medicine. 2015; 15(1):416.

28. Dureja AG, Dhiman K. Free radical scavenging potential and total phenolic and flavonoid content of Ziziphus mauritiana and Ziz iphus nummularia fruit extracts. International Journal of Green Pharmacy. 2012;6(3):187-92. https://doi.org/10.4103/09738258.104929

29. Rajasekaran S, Jaykar B, Anandan R, Aboobacker KP, Vannamalar $\mathrm{S}$. Anti-diabetic activity of leaves of Ziziphus nummularia by dexamethasone induced diabetic rat model. International Journal of PharmTech Res. 2013; 5(2):844-51. https://doi.org/ $10.1155 / 2017 / 4134093$

30. Heather Lord, Janusz Pawliszyn. Journal of Chromatography A. 2000; 885: 153 .

31. Bahmani M, Taherikalani M, Khaksarian M, Soroush S, Ashrafi B Heydari R. Phytochemical profiles and antibacterial activities of hydroalcoholic extracts of Origanum vulgare and Hypericum perforatum and Carvacrol and Hypericin as a Promising Anti-Staphylococcus aureus. Mini Rev Med Chem. 2019;19(11):923-32. https://doi.org/10.2174/1389557519666190121124317

32. Shonouda M, Angeli S, Schutz S, Vidal S. Use of CLSA and SPMEheadspace techniques followed by GC-MS analysis to extract and identify the floral odorants. Pak J BiolSci. 2008;11,1246-51. https://doi.org/10.3923/pjbs.2008.1246.1251

33. Odeh I, AbuU-Lafi S, AL-Najjar I. Determination of Unifloral Honey Volatiles from Centaureaiberica and Ziziphus spina-christi by Solid-Phase Microextraction and Gas Chromatography-Mass Spec- trometry. Acta Chromatographica. https://doi.org/10.1556/AChrom.26.2014.3.7

34. Said A, Huefner A, Abu Tabl ES, Fawzy G. Isolation and identification of two new cyclic amino acids from the seeds of Ziziphus spina-christi L. Willd) by means of 1H-NMR, 13C-NMR, HSQC, HMBC and GC-MS. IUFS J. Biol. 2010;69(1):13-23

35. Prajapati S, Singh S. Phytoconstituents of Ziziphus nummularia (Burm. f.) Wight \& Arn. leaves extracts using GC-MS spectroscopy. Research \& Reviews. 2019; 9(1):109-18

36. Alfarhan AH, Rajakrishnan R, Al-Shehri MA, Al-Tamimi AB, AlObaid S, Khalaf S. Analysis of the cuticular wax composition and ecophysiological studies in an arid plant - Ziziphus nummularia (Burm. f.) Wight \& Arn. Saudi Journal of Biological Sciences. 2020 Jan 1;27(1):318-23. https://doi.org/10.1016/j.sjbs.2019.09.030

37. Duke J. Dr Duke's phytochemical and ethnobotanical databases. 2014. Available from: http://www.ars-grin.gov/duke. Accessed on 1 December 2019

38. Diezel W, Schulz E, Shanks M, Heise H. Plants oils: Topical application and anti-inflammatory effects (Croton oil test). Dermatologische Monatsschrift. 1993;179:173-76.

39. Letawe C, Boone M, Pierard GE. Digital image analysis of the effect of topically appliedlinoleic acid on acne microcomedones. Clinical and experimental Dermatology. 1998;23(2):56-58 https://doi.org/10.1046/j.1365-2230.1998.00315.x

40. Kagoura M, Matsui C, Morohashi M. Carcinogenicity study of phytol (3,7,11,15-tetramethyl-2 hexadecen-1-ol) in ICR mice. J Investig Dermatol. 1993;101:460

41. Pal DK, Nandi M. CNS activities of Celesia coromandeliana Vahl. in mice. Acta Pol Pharm and Drug Res. 2005;62:355-61 